Abstracta Iranica Abstracta Iranica

Revue bibliographique pour le domaine irano-aryen

Volume 26 | 2005

Comptes rendus des publications de 2003

\title{
Ardestān-nāme. 2 vols, Tehrān, Vezārat-e farhang va eršād-e eslāmī, 1381/2003, 1185 p.
}

\section{David Durand-Guédy}

\section{(2) OpenEdition \\ 12 Journals}

\section{Édition électronique}

URL : http://journals.openedition.org/abstractairanica/2548

ISSN : 1961-960X

\section{Éditeur :}

CNRS (UMR 7528 Mondes iraniens et indiens), Éditions de l'IFRI

Édition imprimée

Date de publication : 15 mai 2005

ISSN : 0240-8910

\section{Référence électronique}

David Durand-Guédy, « Ardestān-nāme. 2 vols, Tehrān, Vezārat-e farhang va eršād-e eslāmī, 1381/2003,

1185 p. », Abstracta Iranica [En ligne], Volume 26 | 2005, document 177, mis en ligne le 08 décembre

2005, consulté le 25 septembre 2020. URL : http://journals.openedition.org/abstractairanica/2548

Ce document a été généré automatiquement le 25 septembre 2020.

Tous droits réservés 


\title{
Ardestān-nāme. 2 vols, Tehrān, Vezārat-e farhang va eršād-e eslāmī, $1381 / 2003,1185 \mathrm{p}$.
}

\author{
David Durand-Guédy
}

1 Ces deux volumes regroupent 55 articles consacrés à la région d'Ardistān, dans la province d'Iṣfahān. Située en bordure du désert à mi-chemin entre Kāšān et Nā’īn, la région est surtout célèbre pour ses deux mosquées saljuqides; l'un des enjeux de ce recueil d'articles, dont les auteurs sont des érudits locaux, est de montrer que sa richesse va bien au-delà.

2 Plusieurs articles de synthèse présentent la géographie d'Ardestān (not. pp. 987-1105) et les principaux monuments de la région (pp.33-175). Des études locales sont consacrées à une circonscription donnée (Garmsīr), une ville (Zavāre) ou un village (Kahyāz). La majorité des articles abordent des suj ets précis : la bibliographie (compterendu des articles parus sur Ardistān dans les grandes encyclopédies); la géographie (les techniques de l'eau ; la grenade d'Ardistān) ; l'architecture (la mosquée du vendredi d'Ardistān, les monuments de Sarhang-Ābād, la pierre tombale d'Amīr Uways Āl-e Nūširavān; le qanāt à deux étages d'Ardistān); la lexicologie (les expressions liées à l'eau); l'ethnographie (transcription du texte complet d'un ta'zìye; les gitans d'Ardistān, qui sont appelés «fuyūj »); la sociologie (les structures éducatives dans la région d'Ardistān ; les propriétaires du village de Kahyāz) ; la littérature (Ardistān dans le TārīH-e Gìtī-Gošă de Muhammad Ṣādiq Mūsavī Iṣfahānī ; Ardistān vu par les poètes du Taḍkere de Naṣr-Ābādī); la biographie de poètes locaux (Sodā'î Bayāḍe'î Jandaqī, Rowšān Ardistānī, Kūčak-'Alī Neysiyānī, Fadāye Ardistānī, Sepehrī Zavārēī).

En dehors d'I. Afs̃ār, dont l'étude est la plus longue, les trois principaux contributeurs sont M. Šafīì î-Ardistānī, E. Hāšimī-Ardistān̄̄ et M. Muhịiț-Ṭabāṭabā'̄i. La grande variété des sujets traités, ainsi que la bonne tenue générale des articles (dans leur grande majorité inédits), rendent cet ouvrage intéressant pour les chercheurs travaillant dans les domaines les plus divers. Cependant, on remarquera que l'histoire est peu abordée, si ce n'est à travers le thème des fondations pieuses (vaqf) ou de façon anecdotique (l'un 
des lieutenants de Ḥasan-e Șabbāḥ était natif d'Ardistān...). Il n'y a aucune carte de synthèse permettant de se repérer (sauf à l'intérieur de l'article sur Zavāre). Surtout, le choix de classer les articles par auteur plutôt que par thème est un défi au bon sens et a pour conséquence d'égarer le lecteur. Si l'on en croit l'introduction, deux autres volumes devraient suivre (l'un rassemblant des articles, l'autre étant une bibliographie).

INDEX

Thèmes : 4.0. Généralités

nompropre Nașr-Ābādī

\section{AUTEURS}

DAVID DURAND-GUÉDY

IFRI - Téhéran 